\title{
Total and specific immunoglobulin E and their relationship to respiratory symptoms in Québec children and adolescents
}

\author{
Benoît Lévesque MD MSc ${ }^{1,2,3}$, Jean-François Duchesne $\mathrm{MSc}^{1,2}$, Suzanne Gingras $\mathrm{MSc}^{1}$, Pierre Allard $\mathrm{PhD}^{4}$, \\ Edgar Delvin $\mathrm{PhD}^{4}$, Jacinthe Aubin $\mathrm{MA}^{5}$, Marc Rhainds $\mathrm{MD} \mathrm{MSc}^{1,2,3}$, Pierre Lajoie $\mathrm{MD} \mathrm{MPH}^{1,2,3}$, Pierre Ernst $\mathrm{MD} \mathrm{MSc}^{6}$
}

B Lévesque, J-F Duchesne, S Gingras, et al. Total and specific immunoglobulin $\mathrm{E}$ and their relationship to respiratory symptoms in Québec children and adolescents. Can Respir J 2005;12(8):426-432.

BACKGROUND: Respiratory disease is a major cause of morbidity in young people. It is now recognized that atopy plays an important role in the development of chronic respiratory symptoms in children. OBJECTIVE: To examine the determinants and consequences of serum total and specific immunoglobulin $\mathrm{E}(\mathrm{IgE})$ in a general population sample of Québec children and adolescents.

METHODS: In 1999, 2349 children and adolescents (nine, 13 or 16 years of age) who had participated in a respiratory symptom and disease questionnaire had their total IgE measured. Of these participants, a subsample of 451 children and adolescents was analyzed to detect antibodies to eight specific allergens (ie, allergens of dust mites [Dermatophagoides farinae and Dermatophagoides pteronyssinus], cat, dog, ragweed, Timothy grass, mould [alternaria] and cockroach).

RESULTS: The geometric mean of the total $\operatorname{IgE}$ was $44.4 \mathrm{U} / \mathrm{mL}$ among all participants. Concentrations were higher in boys and increased with age. More than $41 \%$ of the participants were sensitized to at least one specific allergen. Such sensitization was strongly associated with the occurrence of respiratory conditions and symptoms, namely asthma, wheezing and rhinitis. Family history, school location and ethnic origin had an impact on the prevalence of atopy and total IgE levels. CONCLUSIONS: Allergic sensitization is a major determinant in the development of asthma, wheezing and rhinitis in children and adolescents in the province of Québec.

Key Words: Adolescence; Allergens; Asthma; Atopy; Child; Respiratory illnesses; Rhinitis; Specific IgE; Total IgE
Les immunoglobulines E, totales et spécifiques, et leur lien avec les symptômes respiratoires chez les enfants et les adolescents au Québec

CONTEXTE : Les maladies respiratoires constituent une cause importante de morbidité chez les jeunes. Il est reconnu maintenant que l'atopie joue un rôle important dans l'apparition des symptômes respiratoires chroniques chez les enfants.

BUT : L'étude avait pour but d'examiner les déterminants et les conséquences des immunoglobulines $\mathrm{E}$ ( $\mathrm{IgE}$ ) sériques, totales et spécifiques, dans un échantillon d'enfants et d'adolescents, tiré de la population en général, au Québec.

MÉTHODE : En 1999, il y a eu mesure des IgE totales chez 2349 enfants et adolescents $(9,13$ et 16 ans) qui avaient rempli un questionnaire sur les maladies et les symptômes respiratoires. On a analysé parmi eux, dans un sous-échantillon de 451 enfants et adolescents, la présence d'anticorps à l'égard de huit allergènes spécifiques (acariens détriticoles [Dermatophagoides farinae, Dermatophagoides pteronyssinus], chats, chiens, herbe à poux, phléole des prés, moisissure [alternaria] et coquerelles). RÉSULTATS : La moyenne géométrique des IgE totales était de 44,4 U/mL parmi tous les participants. La concentration était plus élevée chez les garçons et elle augmentait avec l'âge. Plus de $41 \%$ des participants présentaient une sensibilisation à au moins un allergène spécifique. Cette sensibilisation s'est montrée fortement associée à l'apparition d'affections et de symptômes respiratoires, soit l'asthme, le wheezing et la rhinite. Les antécédents familiaux, l'emplacement des écoles et l'origine ethnique influaient sur la prévalence de l'atopie et les taux d'IgE totales.

CONCLUSION : La sensibilisation allergique constitue un déterminant important de l'apparition de l'asthme, du wheezing et de la rhinite chez les enfants et les adolescents au Québec.

A topy is recognized as a risk factor for infantile asthma (1,2), recurrent episodes of wheezing $(3,4)$ and bronchial hyperreactivity (5). Atopy therefore plays a major role in the incidence and severity of chronic respiratory symptoms in children. The allergens most frequently identified in relation to asthma are those associated with dust mites, domestic animals (cats and dogs), pollen and cockroaches (1,4,6-9).

Clinical and epidemiological studies (10) now commonly measure total and specific immunoglobulin $\mathrm{E}(\mathrm{IgE})$ in serum. Studies on this subject (11) show a large variability between populations; specifically, they show variability in total IgE levels and the prevalence of atopy to different allergens, in the relationship

between total and specific $\operatorname{IgE}(11-14)$, in the relationship between total or specific IgE and respiratory symptoms $(3,4,15)$, and in the relationships between total or specific $\operatorname{IgE}$ and variables such as sex, age, smoking and family history $(10,13,16,17)$.

To evaluate the importance of this issue, the present study examined the relationship between atopy and respiratory problems in young people in Québec. More specifically, for the population of Québec children and adolescents aged nine, 13 or 16 years, the study aimed to determine the levels of total and specific IgE, as well as the relationship between serum IgE and respiratory symptoms, and the factors associated with variations in IgE, such as age, sex, smoking and family history.

${ }^{1} \mathrm{CHUL}-\mathrm{Centre}$ de recherche du CHUQ, Unité de recherche en santé publique, Sainte-Foy; ${ }^{2}$ Direction de santé publique de Québec;

${ }^{3}$ Institut national de santé publique du Québec, Québec; ${ }^{4}$ Département de biochimie, Hôpital Sainte-Justine; ${ }^{5}$ Direction Santé Québec,

Institut de la statistique; ${ }^{6}$ Department of Medicine, McGill University, Montréal, Québec

Correspondence: Dr Benoît Lévesque, Unité de recherche en santé publique du CHUL-CHUQ, 945, avenue Wolfe, Sainte-Foy, Québec G1V 5B3.

Telephone 418-650-5115 ext 5214, fax 418-654-3134, e-mail Benoit.Levesque@inspq.qc.ca 


\section{METHODS}

The study population consisted of children and adolescents who participated in the Health and Social Survey of Québec Children and Youth (HSSCY) conducted by Santé-Québec (18). A total of 3665 subjects, aged nine $(n=1267), 13(n=1186)$ or 16 years $(n=1212)$, participated in the survey. According to the complex survey design (18), the participants were chosen from 189 schools selected throughout Québec (approximately 60 schools for each age group and approximately 25 students in each school), except for schools on reserves and schools located in very remote regions.

Venous blood was obtained from 2349 participants (733 aged nine years, 773 aged 13 years and 843 aged 16 years). Except for wheezing among 13-year-old children, in whom the proportion of subjects with this symptom was slightly higher among those who had venipuncture $(9.0 \%$ versus $4.6 \%, \mathrm{P}=0.052)$, no significant differences were found between subjects who agreed to have blood samples collected and those who did not; specifically, no differences were found in age, sex and household income groups, as well as in asthma-related symptoms and clinical entities (ie, wheezing, reported asthma, rhinitis, rhinoconjunctivitis, hay fever and other allergies) (18).

Of the 2349 participants, a subsample was selected for specific $\mathrm{IgE}$ analysis. From the 499 young people reporting at least one respiratory problem (ie, wheezing, asthma, hay fever, rhinitis or rhinoconjunctivitis), 232 were randomly selected. From the 1850 young people with none of these problems, 219 were also randomly selected. Blood samples from these 451 subjects were analyzed to detect antibodies against specific allergens.

In the HSSCY survey (18), a weighted sample was obtained to represent the entire Québec population for each of the three age groups. For the sample of 2349 participants, the weighting was adjusted for selection probability, nonresponse and population adjustment (18). For specific IgE, an additional adjustment was performed to correct for the bias induced by the different probabilities of selection between symptomatic and nonsymptomatic subjects, so as to apply the results to all of the young people who participated in the survey. The HSSCY protocol was approved by Santé-Québec's ethics committee, and the parents of the participants provided written informed consent.

Information on asthma and allergic rhinitis was obtained through a self-administered questionnaire to the parents containing the questions of the International Study of Asthma and Allergies in Childhood (ISAAC). The questionnaire was developed and validated in English, and translated into several languages including French (19).

Wheezing in the past 12 months (wheezing) and lifetime asthma (asthma) were respectively determined as a positive answer to the questions, "Has your child had wheezing or whistling in the chest in the last 12 months?" and "Has your child ever had asthma?" Rhinitis in the past 12 months (rhinitis), rhinoconjunctivitis in the past 12 months (rhinoconjunctivitis) and lifetime hay fever (hay fever) were respectively determined by the questions, "In the past 12 months, has your child had a problem with sneezing or a runny or blocked nose when he/she did not have a cold or the flu?", "In the past 12 months, was this nose problem accompanied by itchywatery eyes?" and "Has your child ever had hay fever?"

The HSSCY questionnaire also contained questions on age, sex, socioeconomic status (family income), family history of asthma and hay fever, active smoking in two categories (nonsmokers and smokers [defined as people who had smoked at least 100 cigarettes in their lives and who had smoked within the 30 days preceding the survey]), exposure to secondhand smoke, the presence of cats and dogs in the home, crowding (number of people living in the home divided by the number of rooms in the home), cultural group (Canadian or parent of another culture [eg, Vietnamese, Jamaican]), the presence of carpets (in the main room or in the bedroom) and the location of the school attended (municipalities with 50,000 or fewer inhabitants, or municipalities with greater than 50,000 inhabitants).

Total IgE was measured by a double antibody sandwich immunoassay using alkaline phosphatase and chemiluminescence for signal detection (Beckman Coulter, USA). The functional detection limit was $0.05 \mathrm{U} / \mathrm{mL}$ and the dynamic range reached $1200 \mathrm{U} / \mathrm{mL}$. Samples above $1200 \mathrm{U} / \mathrm{mL}$ were diluted by a factor of 10 with sample diluent and then reanalyzed.

The eight allergens studied were selected on the basis of their documented or presumed correlation with respiratory problems in North America, namely, antigens of dust mites (Dermatophagoides farinae [Der f] and Dermatophagoides pteronyssinus [Der p]), cats, dogs, Timothy grass, moulds (Alternaria tenuis), cockroaches and ragweed (Ambrosia artemisiifolia). The specific IgE of the different antigens was measured using an immunoassay (Allercoat 6 specific IgE assay system, Sanofi-Pasteur, Canada). The test serum was incubated with allergenic proteins bound to a paper ring as a solid support. Once fixed on the allergens, the specific IgE was measured using an anti-IgE antibody paired with alkaline phosphatase, and colourimetric detection was used to evaluate the concentration. The response obtained was semiquantitative and varied by units from zero to six, according to a standard curve. Any sample with a level of two or more was considered positive.

The total IgE followed a log normal distribution; therefore, the geometric mean was used and reported with its 95\% CI. Geometric means of total $\operatorname{lgE}$ in relation to different variables (ie, age, sex and sensitization to specific allergens) were compared using analysis of variance on the logarithm of the values of total IgE. The tendency test for changes in the means of total $\operatorname{IgE}$ in relation to the number of specific IgE was performed using linear regression of the logarithm of the total IgE values. The $\chi^{2}$ test was used to compare proportions, and the Mantel-Haenszel $\chi^{2}$ test was used for evaluating trends across groups. By controlling for the effects of age, sex, family history of asthma and hay fever, logistic regression was used to verify the relationship between specific $\operatorname{IgE}$ and the risk factors, whereas multiple linear regression was used to delineate the independent determinants of total IgE. The alpha statistical significance threshold was set at $5 \%(\mathrm{P} \leq 0.05)$. The sensitivity, specificity, and the positive and negative predictive values of a concentration of $100 \mathrm{U} / \mathrm{mL}$ of total $\mathrm{IgE}$ in relation to a diagnosis of atopy, as defined by a positive response to at least one specific allergen, were also calculated.

Given that the data concerning total and specific IgE were weighted to be representative of the entire population of the province, the number of participants in the Results section and in the Tables was not specified. Instead, estimates of the means and proportions of the population are presented.

\section{RESULTS}

Values obtained for total IgE ranged from $0 \mathrm{U} / \mathrm{mL}$ to $7542 \mathrm{U} / \mathrm{mL}$ (Table 1). The geometric mean of the total IgE for all of the samples was $44.4 \mathrm{U} / \mathrm{mL}$. The mean concentration obtained for boys $(51.8 \mathrm{U} / \mathrm{mL})$ was significantly higher than for girls (38.0 U/mL). This difference between sexes was significant for each of the age categories (Table 1). Furthermore, the geometric mean of the total IgE increased significantly with age. 
Table 2 presents the results of the analyses carried out to detect specific allergies. Only two samples were positive for mould allergens (alternaria) and two for cockroach allergens. As a result, these two allergens could not be taken into account in subsequent statistical analyses; thus, these two allergens were not statistically analyzed as a simple determinant but were taken into account in the variable 'at least one specific IgE'. It was estimated that $21.6 \%, 21.2 \%$ and $17.9 \%$ of children and adolescents were sensitized to the allergens of dust mites, cats and dogs, respectively (Table 2). Eleven per cent were sensitized to both dust mites and cats, and $4.7 \%$ were

TABLE 1

Total immunoglobulin $E$ by age and sex in nine-, 13- and 16-year-old children and adolescents

\begin{tabular}{|c|c|c|c|}
\hline & \multicolumn{3}{|c|}{ Total immunoglobulin E } \\
\hline & $\begin{array}{c}\text { Geometric } \\
\text { mean }(\mathrm{U} / \mathrm{mL})\end{array}$ & $95 \% \mathrm{Cl}$ & $\begin{array}{l}\text { Range } \\
\text { (U/mL) }\end{array}$ \\
\hline \multicolumn{4}{|c|}{9 years of age } \\
\hline Boys & 46.1 & $39.4-54.1$ & $0.5-3812$ \\
\hline Girls & 32.0 & $27.5-37.1$ & $0.2-2748$ \\
\hline $\mathrm{P}^{*}$ & 0.001 & & \\
\hline Total & 38.4 & $34.5-42.9$ & $0.2-3812$ \\
\hline \multicolumn{4}{|c|}{13 years of age } \\
\hline Boys & 49.8 & $42.6-58.1$ & $0.0-2637$ \\
\hline Girls & 36.8 & $31.4-43.0$ & $0.4-7542$ \\
\hline$P^{*}$ & 0.007 & & \\
\hline Total & 42.9 & $38.4-48.0$ & $0.0-7542$ \\
\hline \multicolumn{4}{|c|}{16 years of age } \\
\hline Boys & 59.4 & $50.2-70.3$ & $0.0-5841$ \\
\hline Girls & 45.3 & $39.2-52.2$ & $0.4-7480$ \\
\hline $\mathrm{P}^{*}$ & 0.016 & & \\
\hline Total & 51.8 & $46.4-57.9$ & $0.1-7480$ \\
\hline \multicolumn{4}{|l|}{$\mathrm{P}^{\dagger}$} \\
\hline Boys & 0.068 & & \\
\hline Girls & 0.003 & & \\
\hline Total & $\leq 0.0001$ & & \\
\hline \multicolumn{4}{|l|}{ Total } \\
\hline Boys & 51.8 & $47.1-56.8$ & $0.0-5841$ \\
\hline Girls & 38.0 & $34.8-41.4$ & $0.2-7542$ \\
\hline $\mathrm{P}^{*}$ & $\leq 0.0001$ & & \\
\hline Total & 44.4 & $41.6-47.3$ & $0.0-7542$ \\
\hline
\end{tabular}

${ }^{*}$ Comparison of sexes; ${ }^{\dagger}$ Comparison of age groups sensitized to all three of these allergens. The observed proportions for the prevalence of sensitization to Timothy grass and ragweed were $8.1 \%$ and $7.7 \%$ of the studied population, respectively. For all of the population studied, $41.4 \%$ of the young people were sensitized to at least one of the eight specific allergens analyzed. The proportion of subjects who tested positive for dust mite (Der $f$ and Der $p$ ) allergens was significantly higher in boys (Table 2) and, for dust mite and ragweed allergens, it increased with age.

Table 3 presents the relationship between total $\operatorname{IgE}$ and specific IgE. Regardless of the allergen measured, the geometric mean of the total $\mathrm{IgE}$ was always significantly higher in the young people who tested positive for this allergen. This difference remained significant when the young people sensitized to at least one specific allergen were compared with those not sensitized (Table 3 ). The analyses also showed a significant increase in the mean concentration of total $\mathrm{IgE}$ in relation to the number of specific IgE to which a young person was sensitized (Table 3). A total IgE concentration of $100 \mathrm{U} / \mathrm{mL}$ or greater was associated with sensitization to at least one specific antigen, with a sensitivity of $51 \%$ and a specificity of $89 \%$. The positive predictive value was $77 \%$ and the negative predictive value was $72 \%$.

Table 4 shows that sensitization to specific aeroallergens is more common and total $\mathrm{IgE}$ is higher among subjects with any of the respiratory conditions examined. Atopy, defined as a positive reaction to at least one antigen, was significantly associated with all the symptoms. Among the significant results, it was particularly interesting to note that asthma and wheezing were mainly associated with dust mites and cat allergens, as was hay fever. For the latter, as can be expected, a relationship was found between atopy and pollen (Timothy grass and ragweed) allergens. The associations between serum IgE and respiratory conditions and symptoms remained significant after the analyses were stratified by age and sex (data not shown).

The importance of the genetic component in the prevalence of atopy in children and adolescents is shown in Table 5. In fact, young people who have a positive family history of asthma or hay fever are generally more likely to develop atopy. However, it should be noted that the differences observed between the proportions were significant only for cat, dog and Timothy grass. When atopy is defined as sensitization to at least one allergen, the association is significant (Table 5). Furthermore, children and adolescents with one parent who suffers or had previously suffered from asthma or hay fever had a significantly higher level of total $\operatorname{IgE}$ (Table 5).

TABLE 2

Prevalence (\%) of sensitization to specific aeroallergens by sex and age

\begin{tabular}{|c|c|c|c|c|c|c|}
\hline \multirow[b]{2}{*}{ Allergen } & \multirow[b]{2}{*}{ All } & \multicolumn{2}{|c|}{ Sex } & \multicolumn{3}{|c|}{ Age $^{\dagger}$} \\
\hline & & Girls (95\% Cl) & Boys $(95 \% \mathrm{Cl})$ & 9 years $(95 \% \mathrm{Cl})$ & 13 years $(95 \% \mathrm{Cl})$ & 16 years $(95 \% \mathrm{Cl})$ \\
\hline Dust mite & $21.6(17.8-25.3)$ & $16.9(12.1-21.7)$ & $26.3^{*}(20.6-32.0)$ & $16.4(10.3-22.5)$ & $19.3(13.3-25.4)$ & $28.7^{*}(21.5-35.9)$ \\
\hline Der $p$ & $20.0(16.3-23.6)$ & $14.5(10.0-19.0)$ & $25.5^{\star \star}(19.9-31.2)$ & $13.7(8.1-19.4)$ & $19.1(13.1-25.1)$ & $26.7^{\star}(19.7-33.7)$ \\
\hline Cat & $21.2(17.4-24.9)$ & $19.1(14.1-24.2)$ & $23.2(17.7-28.7)$ & $19.4(12.9-25.9)$ & $16.6(10.9-22.3)$ & $27.7(20.6-34.8)$ \\
\hline Dog & $17.9(14.4-21.4)$ & $20.4(15.2-25.6)$ & $15.3(10.6-20.0)$ & $21.2(14.5-27.9)$ & $13.8(8.6-19.1)$ & $19.1(12.9-25.3)$ \\
\hline Ragweed & $7.7(5.2-10.2)$ & $6.7(3.4-10.0)$ & $8.7(4.9-12.5)$ & $3.9(0.7-7.1)$ & $6.7(2.7-10.6)$ & $12.6^{*}(7.1-18.0)$ \\
\hline At least 1 specific lgE & $41.4(36.9-45.9)$ & $39.2(33.0-45.5)$ & $43.5(37.1-50.0)$ & $39.6(31.6-47.6)$ & $37.8(30.4-45.2)$ & $46.8(38.9-54.7)$ \\
\hline
\end{tabular}

${ }^{*} P \leq 0.05 ;{ }^{* *} P \leq 0.01 ;{ }^{\dagger}$ Tendency test. Der $f$ Dermatophagoides farinae; Der $p$ Dermatophagoides pteronyssinus; IgE Immunoglobulin $E$ 
The degree of urbanization in the community where the participant attended school seemed to have some effect on sensitization (Table 6). In fact, for cat and dog allergens, the proportion of young people sensitized to these allergens was higher in those attending schools located in large urban centres (greater than 50,000 inhabitants) than in schools located in smaller municipalities $(50,000$ or fewer inhabitants). The location of the school, however, had no significant effect on the mean total IgE concentration.

TABLE 3

Total immunoglobulin $E$ in relation to sensitization to specific aeroallergens

\begin{tabular}{|c|c|c|c|c|}
\hline Allergen & Status & $\begin{array}{c}\text { Geometric } \\
\text { mean }(U / m L)\end{array}$ & $95 \% \mathrm{Cl}$ & $\mathbf{P}$ \\
\hline \multirow[t]{2}{*}{ Dust mite } & Negative & 23.4 & $19.9-27.6$ & $\leq 0.0001$ \\
\hline & Positive & 198.0 & $158.9-246.6$ & \\
\hline \multirow[t]{2}{*}{ Der $f$} & Negative & 24.4 & $20.7-28.7$ & $\leq 0.0001$ \\
\hline & Positive & 207.3 & $164.2-261.8$ & \\
\hline \multirow[t]{2}{*}{ Der $p$} & Negative & 23.8 & $20.3-28.0$ & $\leq 0.0001$ \\
\hline & Positive & 218.8 & $177.2-270.1$ & \\
\hline \multirow[t]{2}{*}{ Cat } & Negative & 26.7 & $22.5-31.6$ & $\leq 0.0001$ \\
\hline & Positive & 126.6 & $96.2-166.7$ & \\
\hline \multirow[t]{2}{*}{ Dog } & Negative & 32.6 & $27.5-38.6$ & $\leq 0.0001$ \\
\hline & Positive & 67.5 & $46.1-98.9$ & \\
\hline \multirow[t]{2}{*}{ Timothy grass } & Negative & 32.4 & $27.6-38.1$ & $\leq 0.0001$ \\
\hline & Positive & 173.8 & $113.2-266.7$ & \\
\hline \multirow[t]{2}{*}{ Ragweed } & Negative & 31.7 & $26.9-37.5$ & $\leq 0.0001$ \\
\hline & Positive & 180.6 & $112.5-290.0$ & \\
\hline \multicolumn{2}{|l|}{ No allergens } & 18.5 & $15.3-22.3$ & $\leq 0.0001$ \\
\hline \multicolumn{2}{|l|}{ At least 1 allergen } & 99.8 & $81.8-121.7$ & \\
\hline \multicolumn{5}{|l|}{ Number of allergens } \\
\hline \multicolumn{2}{|l|}{0} & 18.5 & $15.3-22.3$ & $\leq 0.0001^{*}$ \\
\hline \multicolumn{2}{|l|}{1} & 50.3 & $36.6-69.1$ & \\
\hline \multicolumn{2}{|l|}{2} & 76.1 & $54.5-106.0$ & \\
\hline \multicolumn{2}{|l|}{3} & 185.4 & $123.6-278.0$ & \\
\hline \multicolumn{2}{|l|}{4} & 307.0 & $213.0-442.4$ & \\
\hline \multicolumn{2}{|l|}{5} & 181.6 & $77.8-424.0$ & \\
\hline \multicolumn{2}{|l|}{6} & 1397.6 & $669.2-2918.9$ & \\
\hline
\end{tabular}

*Tendency test. Der $f$ Dermatophagoides farinae; Der $p$ Dermatophagoides pteronyssinus
Regardless of the allergen, the prevalence of sensitization was always higher in young people with a non-Canadian ethnic origin (Table 6). However, it should be noted that the observed differences were only significant for dust mites (Der f), Timothy grass and ragweed allergens. Furthermore, the analyses showed that the mean total IgE concentrations were significantly higher in young people with a non-Canadian ethnic origin (Table 6).

Analyses did not show any significant relationships between IgE (specific and total) and the following variables: family income, smoking (passive or active), the presence of cats and dogs in the home and occupancy (data not shown). Although no relationship was found between specific $\operatorname{IgE}$ and the presence of carpet in the home, the total IgE concentration was significantly higher $(54.4 \mathrm{U} / \mathrm{mL})$ in those living in a home where the carpets had been removed (or that never had carpet) than in those whose home carpets had not been removed $(39.7 \mathrm{U} / \mathrm{mL})$.

\section{DISCUSSION}

Significant geographical variability exists in the blood levels of total IgE in populations of children. In Denmark, the mean IgE concentration calculated in 508 young people (seven to 16 years of age) was $18 \mathrm{U} / \mathrm{mL}(20)$, whereas in New Zealand,

\section{TABLE 5}

Prevalence (\%) of sensitization to specific aeroallergens and total immunoglobulin $E$ ( $(\mathrm{gE})$ in relation to family history of asthma and hay fever in nine-, 13- and 16-year-old children and adolescents

\begin{tabular}{|c|c|c|}
\hline & \multicolumn{2}{|c|}{ Family history of asthma and hay fever } \\
\hline & Yes $(95 \% \mathrm{Cl})$ & No $(95 \% \mathrm{Cl})$ \\
\hline Dust mite & $26.0(18.8-33.2)$ & $17.9(13.5-22.4)$ \\
\hline Der $f$ & $22.7(15.9-29.6)$ & $16.4(12.1-20.8)$ \\
\hline Der $p$ & $23.7(16.8-30.7)$ & $16.5(12.2-20.8)$ \\
\hline Cat & $28.6(21.2-36.0)$ & $17.2^{*}(12.8-21.6)$ \\
\hline Dog & $23.9(16.9-30.9)$ & $14.7^{*}(10.6-18.9)$ \\
\hline Timothy grass & $14.0(8.3-19.7)$ & $5.3^{\star \star}(2.7-7.9)$ \\
\hline Ragweed & $10.5(5.2-15.8)$ & $6.4(3.5-9.3)$ \\
\hline At least 1 specific lgE & $53.7(45.6-61.9)$ & $34.5^{\star *}(29.0-40.1)$ \\
\hline $\begin{array}{l}\text { Geometric mean of the } \\
\text { total } \lg E(\mathrm{U} / \mathrm{mL})\end{array}$ & $56.3(49.9-63.5)$ & $38.0^{\star \star *}(34.7-41.6)$ \\
\hline
\end{tabular}

${ }^{*} P<0.05 ;{ }^{* *} P<0.01 ;{ }^{* *} P<0.0001$. Der $f$ Dermatophagoides farinae; Der $p$ Dermatophagoides pteronyssinus

\section{TABLE 4}

Prevalence (\%) of sensitization to specific aeroallergens and total immunoglobulin $\mathrm{E}(\mathrm{IgE})$ in relation to respiratory conditions and symptoms

\begin{tabular}{|c|c|c|c|c|c|c|c|c|c|c|c|c|c|c|}
\hline & \multicolumn{2}{|c|}{ Asthma } & \multicolumn{2}{|c|}{ Wheezing } & \multicolumn{2}{|c|}{ Hay fever } & \multicolumn{2}{|c|}{ Rhinitis } & \multicolumn{2}{|c|}{ Rhinoconjunctivitis } & \multicolumn{2}{|c|}{$\begin{array}{l}\text { Presence of at } \\
\text { least } 1 \text { symptom }\end{array}$} & \multicolumn{2}{|c|}{ Other allergies } \\
\hline & Yes & No & Yes & No & Yes & No & Yes & No & Yes & No & Yes & No & Yes & No \\
\hline Dust mite & 39.3 & $18.3^{\star *}$ & 50.2 & $19.0^{* \star *}$ & 55.8 & $18.5^{\star \star \star \star}$ & 48.6 & $17.3^{* \star \star *}$ & 51.5 & $18.3^{* * *}$ & 41.5 & $16.2^{\star \star \star *}$ & 54.0 & $17.8^{* * * *}$ \\
\hline Der $f$ & 37.5 & $16.4^{\star \star \star}$ & 46.4 & $17.2^{\star \star *}$ & 54.5 & $16.5^{\star \star \star \star}$ & 47.2 & $15.3^{\star \star \star *}$ & 51.5 & $16.2^{\star \star \star \star}$ & 39.9 & $13.8^{* \star * \star}$ & 52.2 & $16.0^{* * * *}$ \\
\hline Der $p$ & 36.5 & $16.9^{* *}$ & 50.2 & $17.3^{\star \star \star *}$ & 55.8 & $16.8^{\star \star \star *}$ & 48.6 & $15.5^{\star \star \star \star}$ & 51.5 & $16.5^{\star \star \star \star}$ & 39.7 & $14.3^{\star \star \star \star}$ & 54.0 & $16.1^{\text {****}}$ \\
\hline Cat & 36.4 & $18.4^{\star *}$ & 46.7 & $18.9^{* *}$ & 42.9 & $19.2^{* *}$ & 41.1 & $18.0^{\star \star \star}$ & 41.4 & $18.8^{\star \star}$ & 35.7 & $16.9^{\star \star \star}$ & 47.8 & $18.2^{\star \star \star \star}$ \\
\hline Dog & 21.4 & 17.4 & 32.7 & $16.7^{*}$ & 22.9 & 17.6 & 23.0 & 17.2 & 19.4 & 17.8 & 20.2 & 17.3 & 22.5 & 17.3 \\
\hline Timothy grass & 13.6 & 7.2 & 20.0 & $7.2^{*}$ & 34.0 & $6.2^{\star \star \star *}$ & 19.8 & $6.4^{\star \star}$ & 23.5 & $6.7^{\star \star}$ & 16.3 & $5.9^{\star \star}$ & 18.8 & $7.1^{*}$ \\
\hline Ragweed & 12.9 & 6.5 & 14.2 & 6.8 & 29.0 & $5.8^{\star * \star \star}$ & 19.1 & $5.7^{\star *}$ & 22.5 & $5.8^{\star \star}$ & 15.4 & $5.2^{\star *}$ & 20.3 & $6.4^{\star *}$ \\
\hline At least 1 specific $\lg \mathrm{E}$ & 62.6 & $37.7^{\star \star \star}$ & 73.2 & $38.7^{\star \star \star}$ & 86.3 & $37.7^{\star \star \star \star}$ & 72.2 & $36.7^{\star \star \star \star}$ & 76.5 & $37.7^{\star \star \star \star}$ & 64.3 & $35.2^{\star \star \star \star}$ & 76.6 & $37.5^{\star \star \star \star}$ \\
\hline $\begin{array}{l}\text { Geometric mean of the } \\
\text { total } \lg E(\mathrm{U} / \mathrm{mL})\end{array}$ & 86.5 & $38.8^{* \star * *}$ & 116.2 & $40.3^{* * * *}$ & 121.1 & $36.8^{\star \star * \star}$ & 92.4 & $35.3^{\star \star \star *}$ & 126.7 & $38.8^{* * * *}$ & 87.2 & $37.0^{\star \star \star \star}$ & 86.1 & $37.3^{\star * * *}$ \\
\hline
\end{tabular}

${ }^{*} P<0.05 ;{ }^{* *} P<0.01 ;{ }^{* \star \star} P<0.001 ;{ }^{* * \star *} P<0.0001$. Der $f$ Dermatophagoides farinae; Der $p$ Dermatophagoides pteronyssinus 


\section{TABLE 6}

Prevalence (\%) of atopy and total immunoglobulin E (IgE) in relation to location of school and cultural group in nine-, 13- and 16-year-old children and adolescents

\begin{tabular}{|c|c|c|c|c|}
\hline & \multicolumn{2}{|c|}{ Location of school $^{\dagger}$} & \multicolumn{2}{|c|}{ Cultural group ${ }^{\dagger \ddagger}$} \\
\hline & $\leq 50,000$ inhabitants $(95 \% \mathrm{Cl})$ & $>50,000$ inhabitants $(95 \% \mathrm{Cl})$ & Canadian $(95 \% \mathrm{Cl})$ & Other $(95 \% \mathrm{Cl})$ \\
\hline Dust mite & $21.4(14.9-27.8)$ & $21.7(17.0-26.3)$ & $20.4(16.3-24.5)$ & $42.1(24.5-59.7)$ \\
\hline Dermatophagoides pteronyssinus & $19.5(13.3-25.7)$ & $20.2(15.7-24.7)$ & $18.8(14.8-22.7)$ & $42.1^{*}(24.5-59.7)$ \\
\hline Cat & $11.7(6.6-16.7)$ & $26.0^{* * *}(21.1-31.0)$ & $21.0(16.8-25.1)$ & $33.1(16.3-49.8)$ \\
\hline Dog & $11.3(6.3-16.2)$ & $21.3^{*}(16.7-25.9)$ & $18.1(14.2-22.0)$ & $30.5(14.1-46.9)$ \\
\hline At least 1 specific lgE & $34.0(26.6-41.4)$ & $45.1(39.5-50.7)$ & $42.1(37.1-47.1)$ & $60.1(42.7-77.5)$ \\
\hline Geometric mean of the total $\lg E(\mathrm{U} / \mathrm{mL})$ & $42.4(38.5-46.6)$ & $45.7(41.9-48.9)$ & $41.8(38.7-45.1)$ & $61.0^{\star \star}(48.3-77.1)$ \\
\hline
\end{tabular}

${ }^{\star} P<0.05 ;{ }^{* \star} P<0.01 ;{ }^{* \star \star} P<0.001 ;{ }^{\dagger}$ Tests were carried out by taking into account the effect of age, sex, family diathesis for asthma and hay fever, the location of residence and cultural group; $¥$ Determined by the cultural group of the responding parent

it was $121 \mathrm{U} / \mathrm{mL}$ in boys and $98 \mathrm{U} / \mathrm{mL}$ in girls aged 11 years (15). The average level observed in the present study was $44.4 \mathrm{U} / \mathrm{mL}$.

We observed a significant difference between the total IgE levels in boys $(51.8 \mathrm{U} / \mathrm{mL})$ and girls $(38.0 \mathrm{U} / \mathrm{mL})$ who participated in the study. Sex-specific differences have also been noted in a population of Japanese children aged 10 to 13 years, in which boys were more prone to have high levels of $\operatorname{IgE}(12)$. However, neither the studies of Backer et al (20) nor Sears et al (15) have shown differences between boys and girls in Danish and New Zealand children, respectively. For adults, European studies $(10,11)$ have shown higher concentrations for males than females, but the data in the literature are not consistent.

Our study also showed that total IgE concentrations increased with age in Québec children and adolescents. However, this result was not seen in a Swedish prospective study in 1984 (21), which showed a decrease in total IgE between the ages of eight and 12 years for 164 children. The cross-sectional design used in the present study limits the interpretation of time-trend tendencies.

Our results for specific IgE estimated that $41 \%$ of the children and adolescents were sensitized to at least one specific allergen (37.7\% in nonasthmatic subjects). These results are consistent with those documented by Laprise and Boulet (22), who established a $42 \%$ prevalence of atopy (reacting to at least one of six groups of allergens by a skin test) in 122 nonasthmatic subjects between 14 and 70 years of age in Québec.

The prevalence of young people sensitized to allergens of the two species of dust mites, and cats and dogs, was relatively high (20\% [Der f], 20\% [Der p], 21\% and 18\%, respectively). In general, these proportions seem to be higher than those measured in other populations of children and adolescents $(9,23)$.

In contrast, the prevalence of atopy to moulds (alternaria) $(0.4 \%)$ and cockroach allergens $(0.7 \%)$ appears to be very low in young people in Québec. In populations living in disadvantaged areas, a cockroach allergy is recognized as an important risk factor in the development of asthma or other health problems (7). The low prevalence of atopy to cockroaches obtained in the present study is possibly due to the sampling method, which did not allow sampling of the populations most at risk. This result could also be due to the northern location of Québec, where cockroaches are possibly less common than in more southernly regions.
Atopy to the allergens of dust mites (Der $f$ and Der $p$ ) and ragweed increased significantly in relation to age in the nine-, 13- and 16-year-old children and adolescents in our study. As already stated, the cross-sectional design of the present study limits the interpretation of data about the course of sensitization to aeroallergens over time. However, in a cohort longitudinal study examining children eight to 10 years of age who were seen at a follow-up of 18 to 20 years of age, Peat et al (24) also showed that the prevalence of atopy to different allergens (ie, house dust mites, rye grass and alternaria) tended to increase with age in young Australians.

Our results found a clear relationship between the total IgE concentrations and sensitization to specific aeroallergens. Laprise and Boulet (22) have also shown a similar relationship in a Québec population aged 14 to 70 years (22). In a population of Danish children, Backer et al (20) also showed that atopy determined by using skin tests was the most important factor explaining variations in total $\mathrm{IgE}$.

Several studies (25-27) on the relationship between serum $\operatorname{IgE}$ and respiratory diseases consider $100 \mathrm{U} / \mathrm{mL}$ to be the limit between a normal and a high blood level of total $\mathrm{IgE}$. The positive predictive value for this concentration was $77 \%$ in relation to a diagnosis of allergic sensitization in the young people studied. We therefore believe that measurement of total $\mathrm{IgE}$ can be a strong indicator of atopy in this population.

The prevalence of respiratory conditions such as hay fever, rhinitis, rhinoconjunctivitis, asthma and wheezing, as documented by the questionnaire response from the parents, is much higher in young people with sensitization to a specific aeroallergen or with a higher level of total IgE. Respectively, $63 \%$ and $73 \%$ of the asthmatic and nonasthmatic subjects reporting wheezing had a specific $\operatorname{IgE}$ to at least one allergen, particularly dust mite and cat allergens (Table 4). This observation was also noted by Sears et al (9) in 13-year-old children in New Zealand. Furthermore, the relationship between serum $\operatorname{IgE}$ (total or specific) and the development of respiratory symptoms has also been noted in several other populations of children $(3,4,12,15,17,20,28)$. Not surprisingly, the occurrence of allergic sensitization and total IgE were higher in those children with a family history of asthma and atopy, as has been found by others $(17,22)$.

In the present study, young people attending schools located in urbanized environments (greater than 50,000 inhabitants) 
developed more sensitization to cat and dog allergens. The studies of Bibi et al (29) and Crimi et al (30) have shown that a higher prevalence of children sensitized to domestic animal allergens is found in urban environments. In adult populations, atopy and allergy symptoms seem to be less common in rural populations $(31,32)$. A few researchers $(31,33)$ state that sensitization at young age to some allergens and even to endotoxins is important in developing a tolerance to allergens. This 'protective' sensitization could be greater in residents of less urbanized environments, mainly for animal allergens.

Young people from a non-Canadian cultural group were, in general, more sensitized to the different allergens and had total IgE levels that were higher than in older-stock Canadians. Few studies have attempted to describe the variations in serum $\mathrm{IgE}$ in relation to race. In the United States, Joseph et al (34) observed that the prevalence of atopy to the allergens of ragweed and another herbaceous plant (bluegrass) in black (Afro-American) children (six to eight years of age) was significantly higher than that measured in white (European American) children. In addition, total IgE levels were also higher in black children. In some populations of Asian children, the serum IgE level considered normal is often very high. In fact, a study carried out on Japanese students (12) set the limit between a normal and high total IgE concentration at $700 \mathrm{U} / \mathrm{mL}$, whereas $94 \%$ of the children aged from 12 to 54 months in a suburb of Bandung, Indonesia, had a total $\operatorname{IgE}$ level greater than $100 \mathrm{U} / \mathrm{mL}$ (35). This finding supports the fact that significant regional variations exist in $\operatorname{IgE}$ (total or

\section{REFERENCES}

1. Sarpong SB, Karrison T. Skin test reactivity to indoor allergens as a marker of asthma severity in children with asthma. Ann Allergy Asthma Immunol 1998;80:303-8.

2. Miraglia Del Giudice M, Pedulla M, Piacentini GL, et al. Atopy and house dust mite sensitization as risk factors for asthma in children. Allergy 2002;57:169-72.

3. Sherrill DL, Stein R, Halonen M, Holberg CJ, Wright A, Martinez FD. Total serum IgE and its association with asthma symptoms and allergic sensitization among children. J Allergy Clin Immunol 1999;104:28-36.

4. Ross S, Godden DJ, Abdalla M, et al. Outcome of wheeze in childhood: The influence of atopy. Eur Respir J 1995;8:2081-7.

5. de Marco R. Determinants of bronchial responsiveness in the European Community Respiratory Health Survey in Italy: Evidence of an independent role of atopy, total serum IgE levels, and asthma symptoms. Allergy 1998;53:673-81.

6. Platts-Mills TA, Carter MC. Asthma and indoor exposure to allergens. N Engl J Med 1997;336:1382-4.

7. Rosenstreich DL, Eggleston P, Kattan M, et al. The role of cockroach allergy and exposure to cockroach allergen in causing morbidity among inner-city children with asthma. N Engl J Med 1997;336:1356-63.

8. Miles J, Cayton R, Ayres J. Atopic status in patients with brittle and non-brittle asthma: A case-control study. Clin Exp Allergy 1995;25:1074-82.

9. Sears MR, Herbison GP, Holdaway MD, Hewitt CJ, Flannery EM, Silva PA. The relative risks of sensitivity to grass pollen, house dust mite and cat dander in the development of childhood asthma. Clin Exp Allergy 1989;19:419-24.

10. Kerkhof M, Droste JH, de Monchy JG, Schouten JP, Rijcken B. Distribution of total serum IgE and specific IgE to common aeroallergens by sex and age, and their relationship to each other in a random sample of the Dutch general population aged 20-70 years. Dutch ECRHS Group, European Community Respiratory Health Study. Allergy 1996;51:770-6.

11. Burney P, Malmberg E, Chinn S, Jarvis D, Luczynska C, Lai E. The distribution of total and specific serum $\operatorname{IgE}$ in the European Community Respiratory Health Survey. J Allergy Clin Immunol 1997;99:314-22. specific) due to different environmental conditions and/or genetic predispositions.

Our results did not show significant relationships between serum $\operatorname{IgE}$ and family income, smoking, the presence of animals (cats and dogs) in the home, occupancy and the presence of carpets in the home. The actual relationship between $\operatorname{IgE}$ and the presence of animals and carpets is difficult to evaluate because parents of children with respiratory symptoms may be more likely to modify the home environment.

The present study is the first to document variations in serum $\operatorname{IgE}$ in a representative population of nine-, 13- and 16-year-old children and adolescents in Québec. It provides information regarding total IgE concentrations and the prevalence of sensitization to eight common aeroallergens, as well as confirming the importance of allergic sensitization in the development of common respiratory conditions. Also, the analyses carried out have provided a better understanding of the relationships between $\operatorname{IgE}$ and respiratory conditions. The present study confirms that sensitization to common aeroallergens is a major factor in the development of asthma in children and adolescents in Québec.

ACKNOWLEDGEMENTS: We thank Pierre Ayotte and Lise Côté for their contribution to this study.

FUNDING: This project was funded by the Fonds de la recherche en santé du Québec (FRSQ) for the Initiative de recherche HydroQuébec sur la santé des enfants et l'environnement.

12. Kagamimori S, Naruse Y, Watanabe M, Nohara S, Okada A. An epidemiological study on total and specific IgE levels in Japanese schoolchildren. Clin Allergy 1982;12:561-8.

13. Omenaas E, Bakke P, Elsayed S, Hanoa R, Gulsvik A. Total and specific serum IgE levels in adults: Relationship to sex, age and environmental factors. Clin Exp Allergy 1994;24:530-9.

14. Remes ST, Korppi M. Asthma and atopy in schoolchildren in a defined population. Acta Paediatr 1996;85:965-70.

15. Sears MR, Burrows B, Flannery EM, Herbison GP, Hewitt CJ, Holdaway MD. Relation between airway responsiveness and serum $\mathrm{IgE}$ in children with asthma and in apparently normal children. N Engl J Med 1991;325:1067-71.

16. Jarvis D, Luczynska C, Chinn S, Burney P. The association of age, gender and smoking with total IgE and specific IgE. Clin Exp Allergy 1995;25:1083-91.

17. Christie GL, Helms PJ, Godden DJ, et al. Asthma, wheezy bronchitis, and atopy across two generations. Am J Respir Crit Care Med 1999;159:125-9.

18. ISQ. Enquête sociale et de santé auprès des enfants et adolescents québécois, 1999. Québec: Direction Santé Québec, Institut de la statistique, 2002:519.

19. Jenkins MA, Clarke JR, Carlin JB, et al. Validation of questionnaire and bronchial hyperresponsiveness against respiratory physician assessment in the diagnosis of asthma. Int J Epidemiol 1996;25:609-16.

20. Backer V, Ulrik CS, Wendelboe D, et al. Distribution of serum IgE in children and adolescents aged 7 to 16 years in Copenhagen, in relation to factors of importance. Allergy 1992;47:484-9.

21. Kjellman NI. Atopic allergy and serum IgE concentrations in randomly selected children followed up from 8 to 12 years of age. Allergy 1984;39:443-50.

22. Laprise C, Boulet LP. Airway responsiveness and atopy in families of patients with asthma. Clin Invest Med 1996;19:461-9.

23. Hader S, Kuhr J, Urbanek R. [Sensitization to 10 important air-borne allergens in school children]. Monatsschr Kinderheilkd 1990;138:66-71.

24. Peat JK, Toelle BG, Dermand J, van den Berg R, Britton WJ, Woolcock AJ. Serum IgE levels, atopy, and asthma in young adults: Results from a longitudinal cohort study. Allergy 1996;51:804-10. 


\section{Lévesque et al}

25. Burrows B, Martinez FD, Halonen M, Barbee RA, Cline MG. Association of asthma with serum IgE levels and skin-test reactivity to allergens. N Engl J Med 1989;320:271-7.

26. Chatain C, Ring J, Schallreuter KU. Total serum immunoglobulins and atopic symptoms in patients with vitiligo. Dermatology 1994;189:27-31.

27. Postma DS, Bleecker ER, Amelung PJ, et al. Genetic susceptibility to asthma - Bronchial hyperresponsiveness coinherited with a major gene for atopy. N Engl J Med 1995;333:894-900.

28. Yazicioglu M, Sayinbas P, Ones U, Saltik A, Tugrul M.

Alatop: A new in vitro screening test for atopy. J Int Med Res 1994;22:313-22.

29. Bibi H, Shoseyov D, Feigenbaum D, et al. Comparison of positive allergy skin tests among asthmatic children from rural and urban areas living within small geographic area. Ann Allergy Asthma Immunol 2002;88:416-20.

30. Crimi P, Boidi M, Minale P, Tazzer C, Zanrdi S, Ciprandi G. Differences in prevalence of allergic sensitization in urban and rural school children. Ann Allergy Asthma Immunol 1999;83:252-6.
31. Leynaert B, Neukirch C, Jarvis D, Chinn S, Burney P, Neukirch F Does living on a farm during childhood protect against asthma, allergic rhinitis, and atopy in adulthood? Am J Respir Crit Care Med 2001;164:1829-34.

32. Heinonen OP, Horsmanheimo M, Vohlonen I, Terho EO. Prevalence of allergic symptoms in rural and urban populations. Eur J Respir Dis Suppl 1987;152:64-9.

33. Braun-Fahrlander C, Riedler J, Herz U, et al. Environmental exposure to endotoxin and its relation to asthma in school-age children. N Engl J Med 2002;347:869-77.

34. Joseph CL, Ownby DR, Peterson EL, Johnson CC. Racial differences in physiologic parameters related to asthma among middle-class children. Chest 2000;117:1336-44.

35. Kartasamita CB, Rosmayudi O, Demedts M. Total serum IgE and eosinophil count in children with and without a history of asthma, wheezing, or atopy in an urban community in Indonesia. The Respiratory Disease Working Group. J Allergy Clin Immunol 1994;94:981-8. 


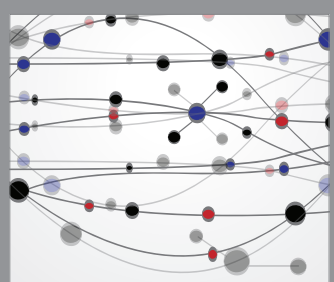

The Scientific World Journal
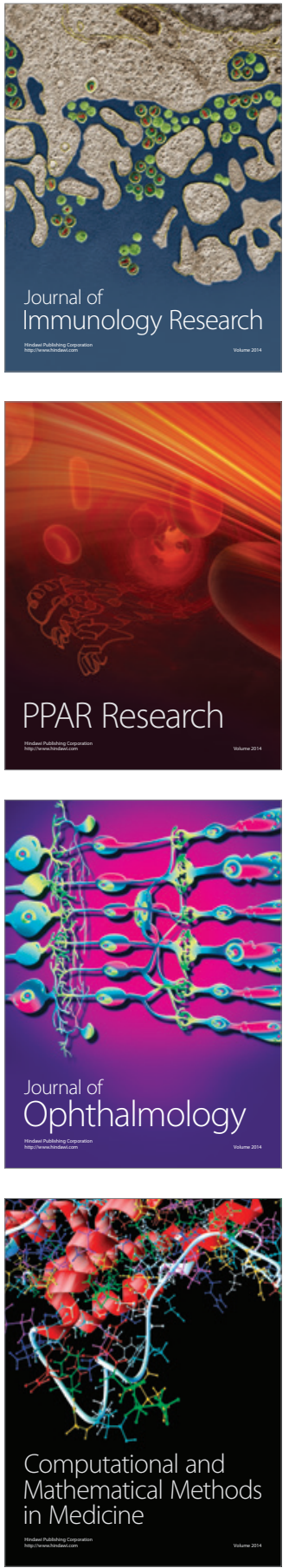

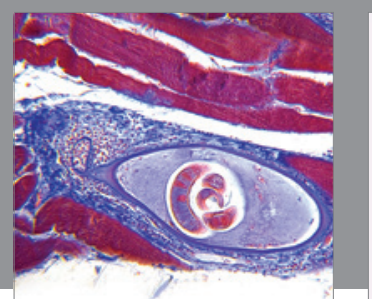

Gastroenterology Research and Practice

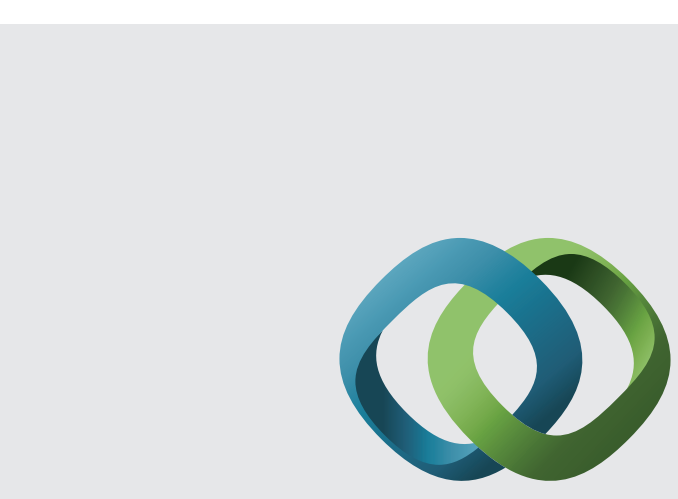

\section{Hindawi}

Submit your manuscripts at

http://www.hindawi.com
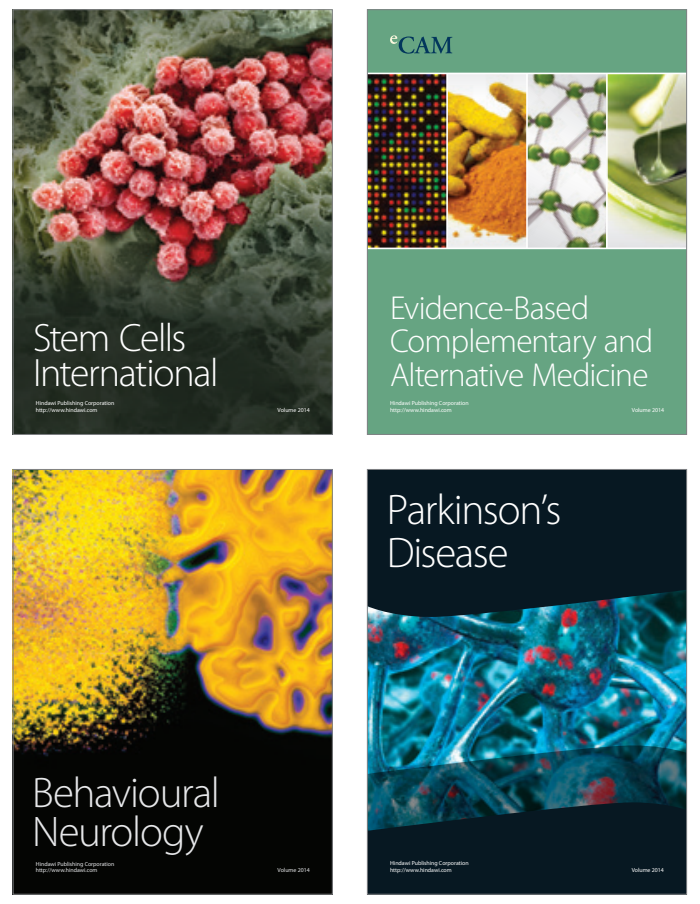
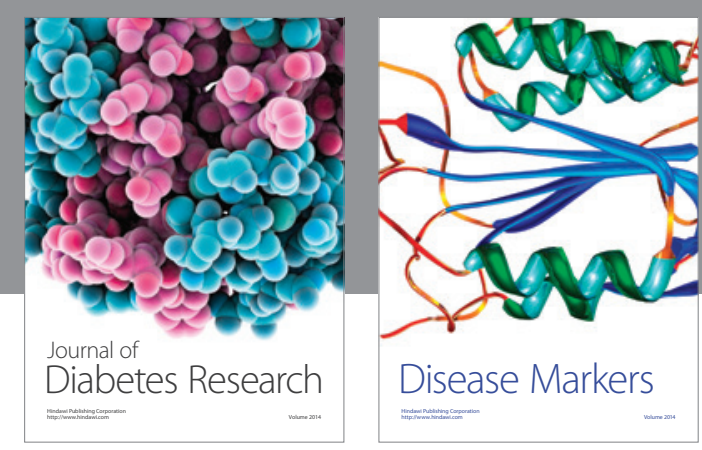

Disease Markers
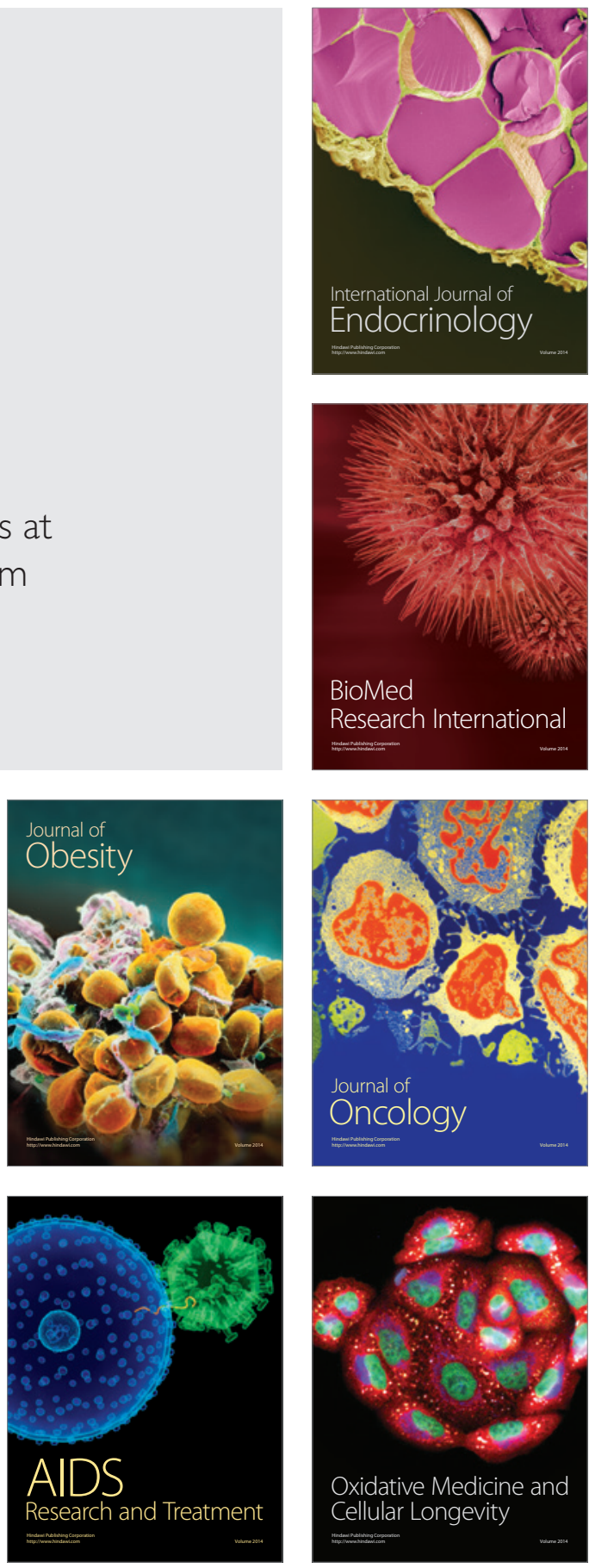